Vol. 44, N. 2 : pp. $197-203$, June, 2001

ISSN 1516-8913 Printed in Brazi

\title{
Histological Analysis of the Callogenesis and Organogenesis from Root Segments of Curcuma zedoaria Roscoe
}

\author{
Marcia O . Mello ${ }^{1}$, Murilo Melo ${ }^{1}$ and Beatriz Appezzato-da-Glória ${ }^{2 *}$ \\ ${ }^{l}$ Center of Agricultural Biotechnology (CEBTEC)/Dept. of Chemistry/ESALQ/ University of São Paulo; ${ }^{2}$ Dept. of \\ Botany/ESALQ/University of São Paulo- Av. Padua Dias, 11 - 13418-900 Piracicaba S.P. Brazil
}

\begin{abstract}
Callus was induced from root segments taken from in vitro grown plants of Curcuma zedoaria Roscoe. The explants were cultured on agar-solidified Murashige and Skoog medium supplemented with $13.4 \mu \mathrm{M}$ of $\alpha$-naphthaleneacetic acid and $2.2 \mu \mathrm{M}$ of 6-benzylaminopurine at $25^{\circ} \mathrm{C}$ in the dark. Histological analysis revealed that callus was formed from the hypertrophied cortical parenchyma cells of the explant. Some of these cells underwent division while the surrounding cells accumulated starch. Callus was capable of shoot bud regeneration after 70 days when it was transfered to liquid medium of the same composition. After 30 days in liquid medium, buds developed from nodular structures. The adventitious shoots developed extensive root systems when they were placed on agar-solidified Murashige and Skoog medium without growth regulators at $25^{\circ} \mathrm{C}$ in the light. The establishment of these plantlets in soil was about $95 \%$.
\end{abstract}

Key words: Adventitious bud, anatomy, morphogenesis, Zingiberaceae

\section{INTRODUCTION}

Zedoary (Curcuma zedoaria Roscoe), a vegetatively propagated species of the Zingiberaceae family, is an aromatic herbaceous plant with a rhizome. As a common house-hold remedy, it has been used extensively as an expectorant, demulcent, diuretic, rubefacient, cholagogue and for treatment of gastritis (Miyake, 1986). Pharmaceutical companies have translated the commercially valuable therapeutic properties of the rhizome into products that medical doctors prescribe to effectively treat gastritis and problems with digestion (Yasuda et al., 1988). In addition to the well-known effect of zedoary as a stomachic, this specie has antiinflammatory potency related to its antioxidant effect (Yoshioka et al., 1998) and has demonstrated to be hepatoprotective (Matsuda et al., 1998) and cytotoxic against human ovarian cancer cells (Syu et al., 1998).

It is important to note that, as is the case with ginger (Babu et al,. 1992), the absence of seed set in Curcuma zedoaria renders conventional breeding methods ineffective. In vitro culture represents an alternative method for the creation and exploitation of the resultant variation. Thus, this technique offers significant potential for crop improvement.

While there are no reports for $C$. zedoaria, morphogenesis in vitro has been reported for some members of the Zingiberaceae family (Roy \& Pal, 1991; Babu et al,. 1992; Balachandran et al., 1990; Kackar et al., 1993; Reghunath \& Priyadarshan, 1993; Dogra et al., 1994; Hung, 1995; Illg \&

Author for correspondence 
Faria, 1995) as well as for the Curcuma genus (Dekkers et al., 1991; Barthakur \& Bordoloi, 1992).

To date, no detailed histological analysis of the complete process of de novo shoot bud formation in Zingiberaceae has been undertaken. The aims of the work were to study the organogenesis in $C$. zedoaria root segment, and to describe the histological changes leading to the induction of meristematic tissue which produces meristemoids and, finally, shoot primordia.

\section{MATERIALS AND METHODS}

Root segment explants of $1 \mathrm{~cm}$ length and $1 \mathrm{~mm}$ diameter were excised from in vitro growing Curcuma zedoaria plants obtained from rhizome cuttings cultured on $0.75 \%(\mathrm{w} / \mathrm{v})$ agar-solidified (Sigma) Murashige \& Skoog (1962) (MS) basal medium. The cultures were incubated at $25^{\circ} \mathrm{C}$ under light with a photoperiod of $16 \mathrm{~h}$ and an irradiance of $30 \mu \mathrm{molm}^{-2} \mathrm{~s}^{-1}$ provided by "Philips" cool white fluorescent tubes. The explants were placed on the same medium, supplemented with $3.0 \% \quad(\mathrm{w} / \mathrm{v}) \quad$ sucrose, $13.4 \mu \mathrm{M}$ of $\alpha$ naphthaleneacetic acid (NAA) and $2.2 \mu \mathrm{M}$ of 6benzylaminopurine (BA). The $\mathrm{pH}$ was adjusted to 5.8 prior to autoclaving. Cultures were incubated in total darkness. After 70 days calluses excised from explants were transfered to MS liquid medium of the same composition and kept under similar conditions.

During the culture, samples were periodically taken and fixed in FAA 50 (Sass, 1951) or Karnovsky solution (Karnovsky, 1965). After fixation in formalin, glacial acetic acid and 50\% ethyl alcohol (FAA 50), samples were dehydrated through an ethanol series, embedded in paraffin, sectioned at $8 \mu \mathrm{m}$ (Sass, 1951) and stained in fuchsin/astra blue combination (Roeser, 1972).
Samples fixed in Karnovsky solution were dehydrated through an ethanol series, and infiltrated with glycol methacrylate resin (Reichert-Jung, Germany). Sections were cut (5 $\mu \mathrm{m}$ ) and stained with toluidine blue $\mathrm{O}$ (Sakai, 1973). All samples were observed with a Nikon (Labophot) microscope. Starch was identified using iodide zinc chloride in non-fixed, free-hand sectioned samples (Strasburger, 1913) and with polarized light in fixed sectioned samples.

Rooting of regenerated shoots was performed in $0.75 \%(w / v)$ agar-solidified (Sigma) MS medium, containing $3.0 \% \quad(\mathrm{w} / \mathrm{v})$ sucrose under the conditions previously described. Acclimatization was performed under greenhouse conditions, in plastic pots consisting of $6 \times 10 \times 15 \mathrm{~cm}$ units containing autoclaved sand, covered with a rigid plastic cover that provided an environment with high relative humidity. Plants were sprayed regularly with water (Illg \& Faria, 1995).

\section{RESULTS AND DISCUSSION}

The anatomy of Curcuma root explants followed the pattern described by Tomlinson (1969) for the Zingiberaceae family. After 3 days of culture, the first explant alterations could be detected when several cortical parenchyma cells were hypertrophied (Figure 1 arrow).

Within 20 days of culture, the histological analysis showed that a large number of lateral roots were produced from the explant pericycle. After 30 days of culture, some of the outer cortical parenchyma cells exhibited starch accumulation and the hypertrophy process intensified resulting in rupture of epidermis. Thus, the callus could be seen on the explant as well as on the surface of its lateral roots. 


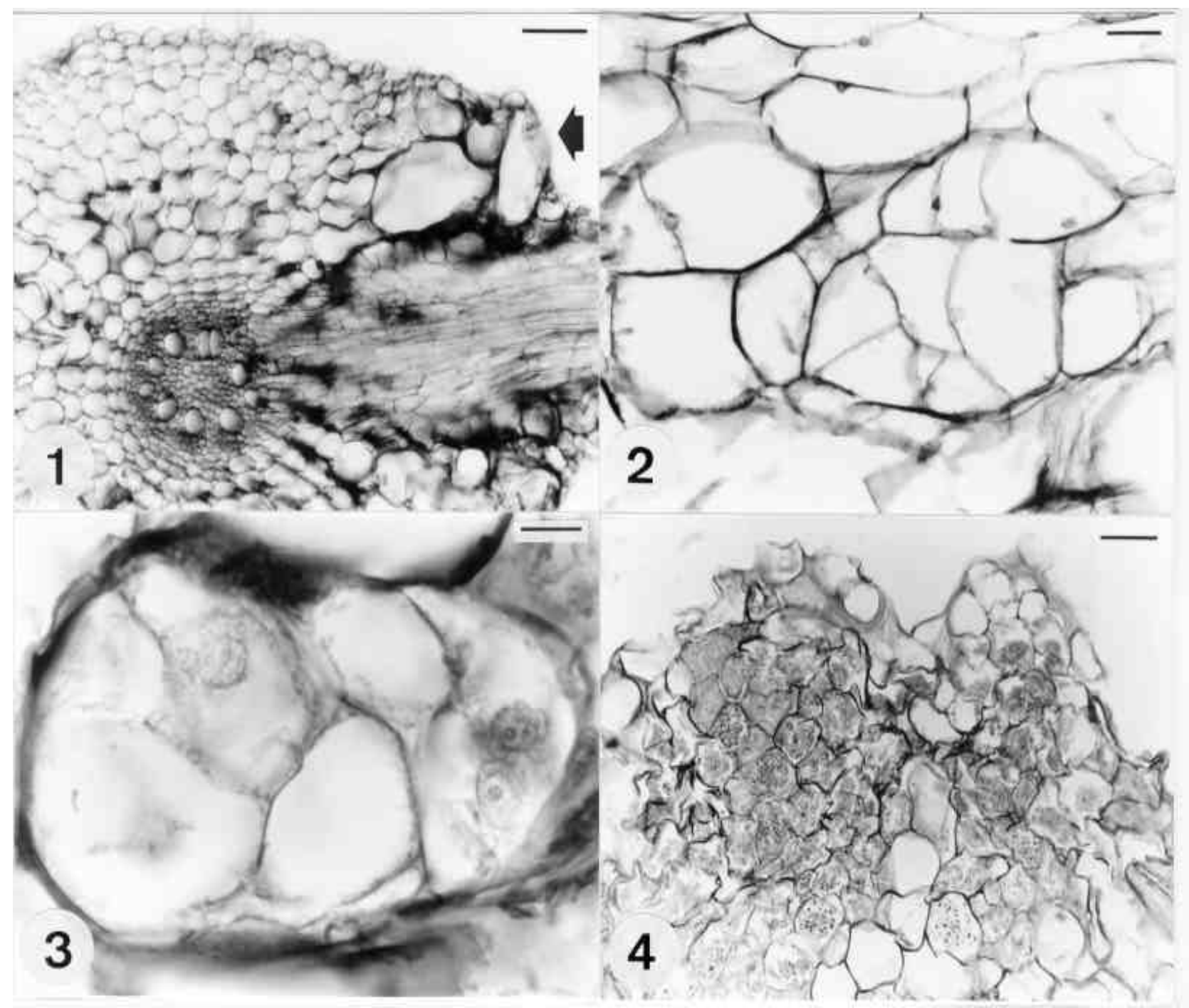

Figure 1-4 - Transverse section of $C$. zedoaria radicular explant cultured in MS solid medium supplemented with $13.4 \mu \mathrm{M}$ NAA and $2.2 \mu \mathrm{M}$ BA in the dark. Figure1- Explant hypertrophied parenchyma cell (arrow) after 3 days in culture. Bar $=100 \mu \mathrm{m}$. Figures 2, 3: Hypertrophied parenchyma cell showing division after 60 days of culture. Bar $=50 \mu \mathrm{m}$ and $10 \mu \mathrm{m}$, respectively. Figure 4: The compact sector of the $C$. zedoaria callus showing starch accumulation after 70 days of culture. Bar $=100 \mu \mathrm{m}$.

Within 60 days of culture, the callus exhibited loosely hypertrophied cells arranged around the vascular cylinder. In some areas the hypertrophied cells divided several times giving rise to various daughter cells included in the original cell wall (Figures 2, 3). Those derived cells were dedifferentiated and also underwent division. Therefore, the callus in Curcuma zedoaria arose from hypertrophied parenchyma cell division. A similar process was reported by Gautheret (1957) in Amorphophallus rivieri. Figueiredo et al. (1989) detected that only the cortical tissue was transformed into callus in Datura insignis. They also observed that the meristematic centers were always formed close to the starch accumulating cells.

Either on one end or on both ends of the explant, several calluses could be observed on a single root after 70 days of culture. In some instances, one or more calluses could also be detected on a lateral root. A similar process was described in Iris by Laublin et al. (1991). At the moment of callus transference in MS liquid medium, its structure was not homogeneous. The inner cells were 
elongated, vacuolated and loosely arranged, giving the callus a friable aspect. However, similar to those reported by Laublin et al. (1991), the outer cells were isodiametric, cytoplasmically dense and closely arranged. These compact sectors of the callus revealed conspicuous levels of starch accumulation (Figure 4).

Soon after being transfered to the MS liquid medium, some of the outer cells of the calluses underwent divisions (Figures 5,6) leading to the formation of meristematic areas similar to those described by Saravitz et al. (1993) as meristemoid areas (Figure 7). These meristemoids were constituted of densely cytoplasmic isodiametric cells with prominent, enlarged nuclei and nucleoli (Figure 7). According to Thorpe (1980), the capacity of a cell to respond to specific signals, probably of a hormonal nature, could lead a parenchyma cell to dedifferentiate; subsequently forming a meristemoid and finally an organ. There is strong evidence that the combination NAA + BA enhances shoot regeneration from Alstroemeria (Gonzales-Benito \& Alderson, 1992) and Dianthus chinensis (Jethwani \& Kothari, 1996) organogenic calluses. The effect of combining these two growth regulators was also described for micropropagation experiments in Curcuma amada (Barthakur \& Bordoloi, 1992) and other members of the Zingiberaceae family (Babu et al., 1992; Reghunath \& Priyadarshan, 1993; Dogra et al., 1994; Hung, 1995; Illg \& Faria, 1995).

The involvement of starch accumulating cells in the shoot-forming process, as described by Sharma et al. (1993), could also be observed in this study.
According to these authors, the degraded byproducts of starch, along with free sugars from the medium were utilized as an energy source for meristemoids and bud differentiation.

After 30 days in MS liquid medium, the meristemoids (Figure 7) elongated vertically and acquired well defined shoot-bud primordial shape (Figures 8,9). The structure of the shoot apex was normal (Figure 10). The top of the axis was domeshaped and two distinct zones were identified: tunica and corpus. Leaf primordia arose gradually around the shoot apex. The area joining the shoot buds to the callus was of significant width and their vascular tissue could be distinctly seen as originating from the callus tissue (Figure 10). The frequency of shoot primordia formation on the surface area of each callus was $2.3 \mathrm{~cm}^{-2}$ (mean of 10 samples).

In order to induce rooting, shoots of $5.0 \mathrm{~cm}$ developed from the callus were placed on agarsolidified MS medium without plant growth regulators, under standard light conditions. An extensive root system developed within 40 days in $100 \%$ of the plantlets. The establishment of the rooted plantlets in sand was $95 \%$ when a high level of humidity was maintained for the first 20 days after transfer to soil.

According to Babu et al. (1992), when already differentiated tissues are used for plant regeneration, there may be an increased rate of somaclonal variation through an intermediary callus phase. This source of variation could be exploited for crop improvement specially since other conventional methods have shown to be ineffective (Silvarolla, 1992) as for C. zedoaria. 


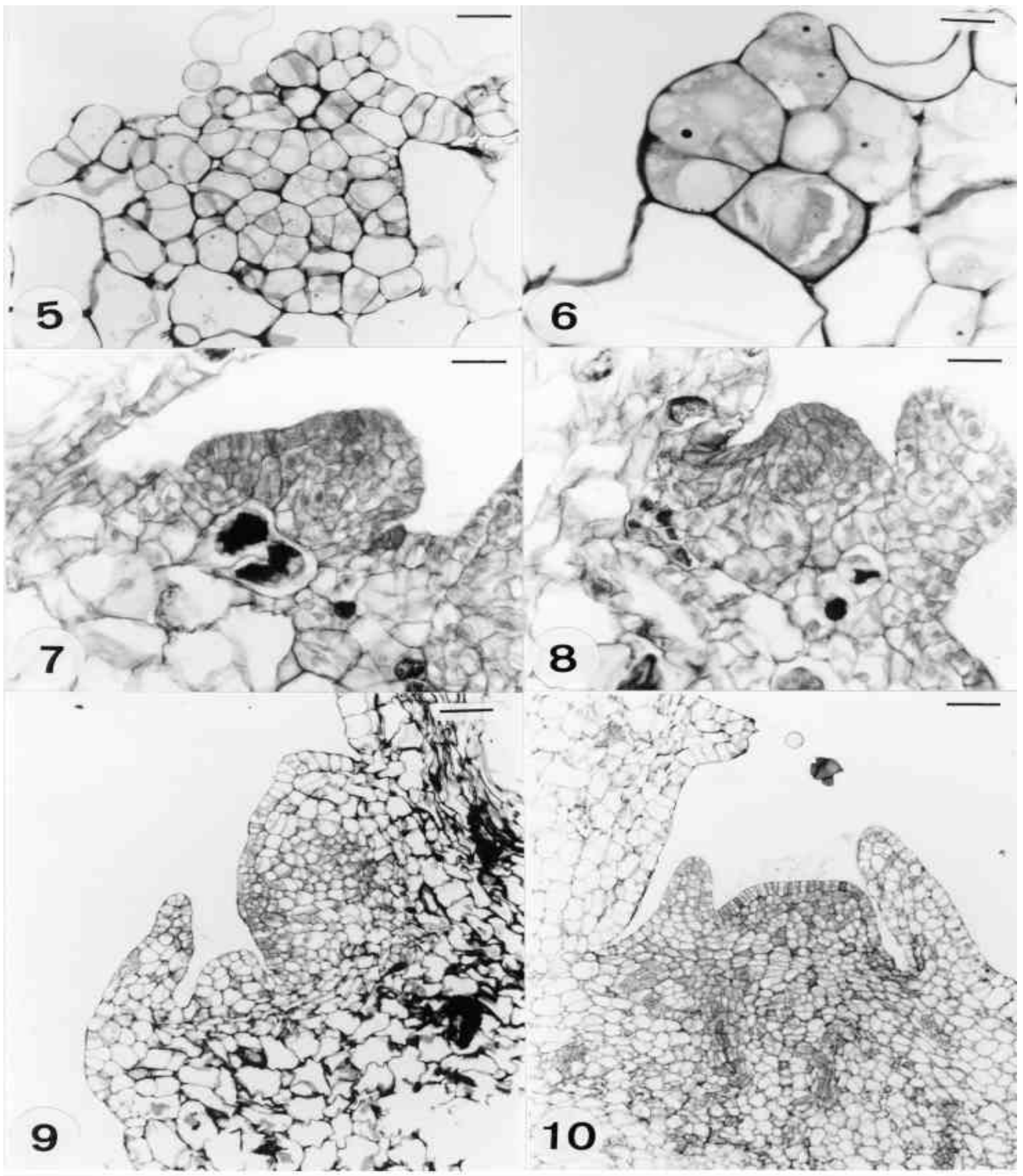

Figure 5 - 10 - Longitudinal axial sections of Curcuma zedoaria Roscoe organogenic calluses cultured in MS liquid medium supplemented with $13.4 \mu \mathrm{M}$ NAA and $2.2 \mu \mathrm{M}$ BA in the dark. Figures 5 and 6- meristematic area after 10 days in liquid medium. Bar $=50 \mu \mathrm{m}$ and $26 \mu \mathrm{m}$, respectively. Figure 7 - meristemoid constituted of isodiametric densely citoplasmic cells after 20 days in liquid medium. Bar $=19 \mu \mathrm{m}$. Figures 8and 9- shoot-bud primordia after 30 days in liquid medium. Bar $=37 \mu \mathrm{m}$ and $100 \mu \mathrm{m}$, respectively. Figure $10-$ shoot apex and its vascular connection with the callus tissue. Bar $=100 \mu \mathrm{m}$. 


\section{ACKNOWLEDGMENTS}

We would like to thank FAPESP for providing financial support for this project.

\section{RESUMO}

Calo de Curcuma zedoaria Roscoe foram induzidos a partir de segmentos de raízes de plantas cultivadas in vitro. Os explantes foram inoculados em meio de Murashige \& Skoog solidificado com ágar e suplementado com $13,4 \mu \mathrm{M}$ de ácido $\alpha$-naftaleno acético e $2,2 \mu \mathrm{M}$ de 6-benzilaminopurina e mantidos no escuro a $25^{\circ} \mathrm{C}$. As análises histológicas realizadas revelaram que os callus eram formados a partir de células hipertrofiadas do parênquima cortical do explante. Algumas destas células entravam em divisão, enquanto as células vizinhas a estas acumulavam amido. Após 70 dias, calos transferidos para meio de Murashige \& Skoog líquido de mesma composição, eram capazes de regenerar plantas. Após 30 dias em meio líquido, gemas se desenvolveram de estruturas nodulares. Estas gemas adventíceas formaram um abundante sistema radicular quando transferidas para meio de Murashige \& Skoog solidificado com ágar, sem regulador de crescimento e mantidas a $25^{\circ} \mathrm{C}$ na luz. A taxa de sobrevivência das plantas foi de $95 \%$.

\section{REFERENCES}

Balachandran, S. M.; Bhat, S. R. and Chandel, K. P. S. (1990), In vitro clonal multiplication of turmeric (Curcuma sp.) and ginger (Zingiber officinale Rosc.). Plant Cell Rep., 8, 521-524

Babu, K. N.; Samsudeen, K. and Ratnambal, M. J. (1992), In vitro plant regeneration from leaf-derived callus in ginger. Plant Cell Tiss. Org. Cult., 29, 71-74

Barthakur, M. P.; Bordoloi, D. N. (1992), Micropropagation of Curcuma amada. J. Spices Arom. Crops, 1, 154-159

Dekkers, A. J.; Rao, A. N. and Goh, C. J. (1991), In vitro storage of multiple shoot cultures of gingers at ambient temperatures of $24-29^{\circ} \mathrm{C}$. Sci. Hortic., 47, 157-167

Dogra, S. P.; Korla, B. N. and Sharma, P. P. (1994), In vitro clonal propagation of ginger (Zingiber officinales Rosc.). Hort. J., 7, 45-50
Figueiredo, S. F. L.; Vieira, R. C.; Esquibel, M. A. and Costa, C. G. (1989), Histogenese de calo de explante caulinar de Datura insignis. Rodriguésia, 67, 71-77

Gautheret, R. T. (1957), Histogenesis in plant tissue cultures. J. Nat. Cancer Inst., 19, 555-590

Gonzalez-Benito, E. and Alderson, P. G. (1990), Regeneration from Alstroemeria callus. Acta Hortic., 280, 135-138

Guenther, E. (1952), The essential oils. D. Van Nostrand, Toronto

Hung, J. H. (1995), In vitro propagation and preservation of ginger germplasm resources. Scientia Agricultura Sinica, 28, 24-30

Illg, R. D. and Faria, R. T. (1995), Micropropagation of Alpinia purpurata from inflorescence buds. Plant Cell Tiss. Org. Cult., 40, 183-185

Jethwani, V. and Kothari, S. L. (1996), Phenylacetic acid induced organogenesis in cultured leaf segments of Dianthus chinensis. Plant Cell Rep., 15, 869-872

Kackar, A.; Bhat, S. R.; Chandel, K. P. S. and Malik, S.K. (1993), Plant regeneration via somatic embryogenesis in ginger. Plant Cell Tiss. Org. Cult., 32, 289-292

Karnovsky, M. J. (1965), A formaldehydeglutaraldehyde fixative of high osmolality for use in electron microscopy. J. Cell Biol., 27, 137-138

Laublin, G.; Saini, H. S. and Cappadocia, M. (1991), In vitro plant regeneration via somatic embryogenesis from root culture of some rhizomatous irises. Plant Cell Tiss. Org. Cult., 27, 15-21

Matsuda, H.; Ninomiya, K.; Morikawa, T. and Yoshikawa, M. (1998), Inhibitory effect and action mechanism of sesquiterpebes from Zedoaria rhizoma on D-galactosamine / lipopolysaccharide-induced liver injury. Bioorg. Med. Chem. Lett., 8, 339-344

Miyake, E. T. (1986), Zedoaria. Rev. Bras. Farmacologia, 1, 192-199

Murashige, T. and Skoog, F. (1962), A revised medium for rapid growth and bioassays with tobacco tissue cultures. Physiol. Plant., 15, 473-497

Reghunath, B. R. and Priyadarshan, P. M. (1993), Somaclonal variation in cardamom (Elettaria cardamomum Maton) derived from axenic culture of juvenile shoot primordia. Acta Hortic., 330, 235-242

Roeser, K. R. (1972), Die nadel der schwarzkiefermassen produkt und kunstwert der natur. Mikrokosmos, 61, 33-36

Roy, A. and Pal, A. (1991), Propagation of Costus speciosus $\mathrm{Sm}$. through in vitro rhizome production. Plant Cell Rep., 10, 525-528

Sakai, W. S. (1973), Simple method for differential staining of paraffin embedded plant material using toluidine blue O . Stain Technol., 48, 247-249

Saravitz, C. H.; Blazich, F. A. and Amerson, H. V. (1993), Histology of in vitro adventitious bud development on cotyledons and hypocotyls of Fraser fir. J. Amer. Soc. Hort. Sci., 118, 163-167 
Sass, J. E. (1951), Botanical microtechnique. Iowa State University Press, Ames

Sharma, K. K.; Yeung, E. C. and Thorpe, T.A. (1993), Histology of shoot bud ontogeny from seedling root segments of Brassica napus L. Ann. Bot., 71, 461466

Silvarolla, M. B. (1992), Plant genomic alterations due to tissue culture. J. Braz. Assoc. Adv. Sci., 44, 329335

Strasburger, E. (1913), Handbook of Pratical Botany. George Allen and Company Ltda., London

Syu, W. J.; Shen, C. C.; Don, M. J.; Ou, J. C.; Lee, G. H. and Sun, C. M. (1998), Cytotoxicity of curcuminoids and some novel compounds from Curcuma zedoaria. J. Nat. Prod., 61, 1531-1534

Tomlinson, P. B. (1969), Anatomy of the Monocotyledons. Oxford University Press, London
Thorpe, T. A. (1980), Organogenesis in vitro: structural, physiological and biochemical aspects. InPerspectives in Plant Cell and Tissue Culture, ed. I.K. Vasil. Academic Press, New York, 71-111

Yasuda, K.; Tsuda, T.; Shimizu, H. and Sugaya, A. (1988), Multiplication of Curcuma species by tissue culture. Planta Medica, 54, 75-79

Yoshioka, T.; Fujii, E.; Endo, M.; Wada, K.; Tokunaga, Y.; Shiba, N.; Hohsho, H.; Shibuya, H. and Muraki, T. (1998), Antiinflammatory potency of dehydrocurdione, a zedoary-derived sesquiterpene. Inflamm. Res., 47, 476-481

Received: December 16, 1999; Revised: June 21, 2000, Accepted: July 13, 2000. 